\title{
Uji Aktivitas Hepatoprotektor Ekstrak Etanol Daun Rambutan (Nephelium lappaceum L.) pada Mencit Putih Jantan yang Diinduksi Parasetamol
}

\section{Hepatoprotective Activity of Rambutan Leaf (Nephelium lappaceum L.) Ethanol Extract in Male Mice Induced by Paracetamol}

\author{
Waode Cahaya Widya Putri ${ }^{1}$, Yuliawati ${ }^{1 *}$, Havizur Rahman ${ }^{1}$ \\ Program Studi Farmasi, Fakultas Kedokteran dan Ilmu Kesehatan, Universitas Jambi, Jambi, Indonesia \\ *E-mail: yuliawati.saputra@gmail.com
}

Received: 10 September 2021; Accepted: 23 Desember 2021; Published: 31 Desember 2021

\begin{abstract}
Abstrak
Hepatotoksik merupakan komplikasi obat yang sering dijumpai pada penggunakan obat jangka panjang karena peran hati dalam memetabolisme obat. Parasetamol merupakan obat penurun demam dan pereda nyeri yang sering digunakan masyarakat serta menjadi pilihan aman bila dikonsumsi sesuai dosis. Akan tetapi jika dikonsumsi berlebihan dan dalam jangka yang panjang dapat mengakibatkan hepatotoksik (kerusakan hati). Kerusakan hati dapat dicegah dengan pemberian senyawa antioksidan. Daun rambutan mengandung metabolit sekunder alkaloid, tannin dan saponin yang diketahui memiliki potensi antioksidan. Tujuan penelitian ialah mengetahui efek hepatoprotektor beserta dosis efektif dari ekstrak etanol daun rambutan pada mencit putih jantan yang diinduksi parasetamol. Metode penelitian yaitu The Randomize Posttest-only Control Group Design menggunakan 25 ekor mencit putih yang dibagi menjadi 5 kelompok. Hasil penelitian memperlihatkan adanya perbedaan bermakna pada kemlompok perlakuan pemberian ekstrak etanol daun rambutan dengan kelompok kontrol negatif dan perbedaan yang tidak bermakna dengan kelompok kontrol positif. Pemberian ekstrak dosis $100 \mathrm{mg} / \mathrm{kg} \mathrm{BB}, 200 \mathrm{mg} / \mathrm{kg}$ BB dan $400 \mathrm{mg} / \mathrm{kg}$ BB karena mencegah peningkatan kadar SGPT, SGOT, bobot hati relatif dan mengurangi persentase kerusakan hepatosit mencit. Dosis efektif ekstrak etanol daun rambutan sebagai hepatoprotektor yaitu $400 \mathrm{mg} / \mathrm{kg} \mathrm{BB}$. Kata Kunci: daun rambutan, hepatoprotektor, SGPT, SGOT dan histopatologi
\end{abstract}

\begin{abstract}
Hepatotoxicity is a drug complication that is often found in long-term drug use because of the role of the liver in metabolizing drugs. Paracetamol is an analgesic and antipyretic drug that is often used by the community and is a safe choice when taken according to the dose. However, if consumed in excess and in the long-term it causes hepatotoxicity (liver damage). Liver damage can be prevented by giving antioxidant compounds. Rambutan's leaves contain secondary metabolites of alkaloids, tannins and saponins which are known to have antioxidant potential. The aim of the research is to determine the hepatoprotective activity and the effective dose of Rambutan leaves ethanol extract in male mice induced by patacetamol. The research method was The Randomize Posttest-only Control Group Design using 25 white mice which were divided into 5 groups. The results showed that there was a significant difference in the treatment group of rambutans leaf ethanol extract with the negative control group and a non-significant with the positive

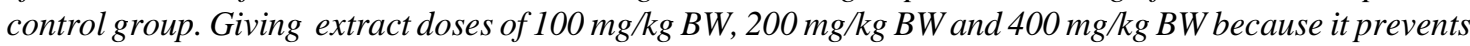
the increase in levels of SGPT, SGOT, relative liver weight and reduces the percentage of damage to the hepatocytes of mice. The effective dose of rambutan's leaf ethanol extract as a hepatoprotector is $400 \mathrm{mg} / \mathrm{kg}$ $B W$.
\end{abstract}

Keywords: Rambutan's leaf, hepatoprotector, SGPT, SGOT and histopathology

\section{PENDAHULUAN}

Hepatotoksik diartikan sebagai kerusakan hati yang diakibatkan oleh induksi obat Parasetamol merupakan obat penurun demam dan pereda nyeri yang sering digunakan masyarakat. Obat ini menjadi pilihan yang aman bila dikonsumsi sesuai dosis yang dianjurkan. Penggunaan parasetamol yang melebihi dosis terapi dapat mengakibatkan kerusakan hati (Neal, 2006). 
Metabolisme parasetamol menjadi produk radikal bebas $N$-asetil-p-benzokuinonimine (NAPQI) terjadi di hati oleh enzim CYP450 2E1. Pada keadaan normal NAPQI berkonjugasi dengan glutation (GSH) membentuk senyawa sistein dan merkapturik yang bersifat non toksik dan nantinya dikeluarkan melalui urin. Pada keadaan toksik akan terbentuk NAPQI yang berlebihan sehingga GSH yang ada tidak cukup untuk mengubah NAPQI menjadi senyawa non toksik. NAPQI akan berikatan dengan hepatosit membentuk NAPQI protein adduct (protein tambahan) yang menyebabkan stress oksidatif dan nekrosis hepatoseluler. Jika terjadi nekrosis, enzim SGPT (Serum Glutamate Piruvat Transaminase) dan SGOT (Serum Glutamate Oxaloacetate) akan keluar ke darah sehingga peningkatan SGPT dan SGOT dapat digunakan sebagai parameter adanya gangguan fungsi hati (Dart, 2004), sehingga dibutuhkan pengobatan efektif yang mampu mencegah kerusakan hati (hepatoprotektor).

Salah satu tumbuhan yang berpotensi dikembangkan untuk obat adalah rambutan (Hidayat and Napitupulu, 2015). Penelitian terdahulu menunjukkan ekstrak etanol daun rambutan memiliki aktivitas antioksidan (Pangaribuan et al., 2016). Antioksidan merupakan senyawa yang dapat digunakan sebagai hepatoprotektor, yang mampu melindungi hati dari kerusakan akibat stress oksidatif (Jurnalis et al., 2014). Ekstrak daun rambutan memiliki nilai IC $_{50}$ sebesar 25,47 $\mu \mathrm{g} / \mathrm{mL}$ yang tergolong sangat kuat (Pangaribuan et al., 2016).

Berdasarkan latar belakang tersebut, maka perlu dilakukan pengujian aktivitas hepatoprotektor ekstrak etanol daun rambutan (Nephelium lappaceum L.) pada mencit putih jantan yang diinduksi parasetamol.

\section{METODE PENELITIAN}

\section{Alat dan Bahan}

Alat yang digunakan yaitu timbangan analitik (Pioneer ${ }^{\circledR}$ ), corong Buchner, rotary evaporator (Heidolph VV-300®), oven
(Memmert $\AA$ ), tanur (Furnace $\AA)$, desikator (Duran $\left.{ }^{\circledR}\right)$, batang pengaduk (Pyrex $\left.{ }^{\circledR}\right)$, krus porselen, tabung reaksi (Pyrex $\left.{ }^{\circledR}\right)$, waterbath chamber (Buchi®), erlenmeyer (Iwaki $\left.{ }^{\circledR}\right)$, gelas ukur (Pyrex®), labu ukur (Pyrex $\left.{ }^{\circledR}\right)$, neraca hewan (Camry $\left.{ }^{\circledR}\right)$, sonde oral $1 \mathrm{ml}$ (Terumo®), alat bedah (Wells spencer®), tabung sentrifus (Vaculab®), pipet mikro (Socorex®), spektrofotometer BTS 350 (Biosystem $\left.{ }^{\circledR}\right), \quad$ Centrifuge (Nesco $\left.{ }^{\circledR}\right)$, mikrotom (Leica $\left.{ }^{\circledR}\right)$, mikroskop (Leica $\left.{ }^{\circledR}\right)$.

Bahan yang dipergunakan ialah daun rambutan (Nephelium lappaceum L.) yang diambil dari Kelurahan Payo Selincah, Kecamatan Paal Merah, Kota Jambi, Provinsi Jambi, pakan mencit, aquadest, etanol teknis $70 \%, 80 \%, 90 \%, 95 \%$ dan $100 \%, \mathrm{HCl} 2 \mathrm{~N}$, pereaksi Mayer, pereaksi Dragendorf, serbuk $\mathrm{Mg}, \mathrm{FeCl}_{3}$, kloroform, $\mathrm{CH}_{3} \mathrm{COOH}$ anhidrat, $\mathrm{H}_{2} \mathrm{SO}_{4}$ pekat, tablet parasetamol, $\mathrm{Na} \mathrm{CMC}$, tablet curcumin, reagen SGPT, reagen SGOT (Diasys), $\mathrm{NaCl} 0,9 \%$, formalin $10 \%$, xilol, paraffin, Hematoksilin Eosin (HE).

\section{Pengelompokkan Hewan Uji}

Hewan uji yang digunakan sebanyak 25 ekor mencit putih jantan dengan berat badan 20-30 gram dan usia 2-3 bulan yang dibagi menjadi 5 kelompok (tiap kelompok 5 ekor mencit) yaitu Kontrol negatif (K-) diberikan $\mathrm{Na} \mathrm{CMC} \quad 0,5 \%$, Kontrol positif $(\mathrm{K}+)$ diberikan Curcuma $260 \mathrm{mg} / \mathrm{kg} \quad \mathrm{BB}$, Kelompok perlakuan 1 (P1) diberikan ekstrak etanol daun rambutan $100 \mathrm{mg} / \mathrm{kg} \mathrm{BB}$, Kelompok perlakuan 2 (P2) diberikan ekstrak etanol daun rambutan $200 \mathrm{mg} / \mathrm{kg} \mathrm{BB}$, Kelompok perlakuan 3 (P3) diberikan ekstrak etanol daun rambutan $400 \mathrm{mg} / \mathrm{kg}$ BB.

\section{Perlakuan Hewan Uji}

Penelitian ini telah lolos uji etik dari komite etik penelitian dengan nomor 3/02/UN28.1.30/KL/2021. Perlakuan hewan uji mengacu pada Sudjono et al (2012), tiap kelompok diberikan perlakuan sesuai pembagian kelompok 1 kali sehari selama 7 hari. Induksi parasetamol peroral dosis 250 $\mathrm{mg} / \mathrm{KgBB}$ (Gunawan, 2016) dilakukan 24 jam sesudah pemberian perlakuan hari terakhir (hari ke-8). Setelah 24 jam pemberian 
parasetamol (hari ke-9), diambil darah mencit pada semua kelompok dan diperiksa kadar SGPT dan SGOT serum mencit. Selanjutnya mencit dibedah dan diambil organ hatinya untuk dilakukan pengamatan makroskopis, penimbangan berat organ hati dan histopatologi hati mencit.

\section{Pengambilan Serum Mencit}

Pengambilan darah dilakukan dengan mengorbankan hewan dengan cara memotong arteri karotis. Darah ditampung dengan tabung Eppendorf dan disentrifugasi dengan kecepatan 3000 rpm selama 15 menit. Cairan bening pada bagian atas dipipet dan dipindahkan ke tabung eppendorf (Meisyayati et al., 2017). Selanjutnya serum diperiksa kadar SGPT serta SGOT dengan reagen kit.

\section{Pembuatan Working Reagent}

Masing-masing reagen I SGOT dan SGPT yang terdiri dari 4 botol dimasukkan ke dalam botol kosong sebanyak $1000 \mu \mathrm{l}$ tiap botol. Kemudian ditambahlan satu bagian reagen II SGOT dan SGPT sebanyak $1000 \mu 1$ dan dihomogenkan.

\section{Prosedur Kerja Pemeriksaan}

Serum darah ditempatkan dalam tabung reaksi sebanyak $100 \mu \mathrm{l}$, ditambahkan dengan $1000 \mu \mathrm{l}$ working reagent SGPT dan dihomogenkan. Selanjutnya, hasil dibaca pada alat spektrofotometer dengan menggunakan panjang gelombang $340 \mathrm{~nm}$. Begitu juga untuk pemeriksaan konsentrasi SGOT.

\section{Pengamatan Makroskopis Organ Hati}

Pengamatan makroskopis organ hati meliputi pengamatan bentuk dan warna permukaan. Hasil yang didapat dicatat dan didokumentasikan.

\section{Hepatosomatic Index (HSI)}

Organ hati yang akan ditimbang, dikeringkan terlebih dahulu dengan menggunakan kertas penyerap kemudian dilakukan penimbangan. Rumus perhitungan Hepatosomatic Index (HSI) adalah sebagai berikut:

$$
\mathrm{HSI}=\frac{\text { Berat organ }(\mathrm{g})}{\text { Berat badan mencit }(\mathrm{g})} \times 100 \%
$$

\section{Pembuatan Preparat Histopatologi}

Hati dicuci dengan $\mathrm{NaCl}$ fisiologis dan ditimbang bobotnya. Kemudian difiksasi dengan formalin $10 \%$ selama 24 jam. Hati yang telah difiksasi selanjutnya didehidrasi menggunakan alkohol bertingkat $(70 \%, 80 \%$, $90 \%$ dan $95 \%$ ) selama masing - masing 24 jam dan dilanjutkan dengan alkohol $100 \%$ selama satu jam dengan pengulangan sebanyak 3 kali. Selanjutnya proses penjernihan dengan xilol selama satu jam sebanyak tiga kali. Lalu diinfiltrasi menggunakan paraffin dan ditanam dalam media paraffin. Setelah jadi dalam bentuk blok, dibuat sayatan jaringan dengan ketebalan $4-5$ mikron. Sayatan yang dihasilkan diwarnai dengan Hematoksilin Eosin (HE) dan preparat yang sudah jadi diamati dibawah mikroskop (BPOM RI, 2014).

\section{Pemeriksaan Histopatologi Organ Hati}

Pengaruh pemberian ekstrak etanol daun rambutan terhadap histopatologi hati mencit dianalisis menggunakan sistem skoring Manja Roegnick. Tahap pertama yaitu pengamatan preparat dengan mikroskop perbesaran 400x sebanyak 5 lapang pandang. Pengamatan dilakukan pada sel hati secara umum untuk mengidentifikasi sel normal dan sel yang rusak. Kemudian dilakukan penilaian dan perhitungan jumlah sel normal $(\mathrm{N})$, sel yang mengalami degenerasi parenkimatosa (DP), degenerasi hidropik (DH) serta nekrosis (NK) . Tiap pengulangan diamati sebanyak 5 lapang pandang, lalu jumlah perhitungan sel dikalikan dengan skor Manja Roenigk. Hasil skoring tersebut kemudian dijumlahkan untuk mendapatkan skor dan persentase kerusakan hepatosit mencit (Tabel 1).

Nilai skor total $=\mathrm{N}+2 \mathrm{DP}+3 \mathrm{DH}+4 \mathrm{NK}$

$(\%)=\frac{\text { Jumlah sel yang ditemukan }}{\text { Jumlah total skoring perlakuan }} \times 100 \%$

\section{Analisis Data}

Pengamatan makroskopis hati dianalisis secara deskriptif. Data kuantitatif hasil 
Tabel 1. Sistem skoring Manja Roenigk

\begin{tabular}{ll}
\hline Jenis degenerasi & Nilai \\
\hline Sel Normal & 1 \\
Degenerasi Parenkimatosa & 2 \\
Degenerasi Hidropik & 3 \\
Nekrosis (sel piknotik, 4 \\
karioreksis kariolisis) \\
Keterangan: (1): Hepatosit normal, sel berbentuk \\
polygonal, sitoplasma berwarna merah homogen, \\
dinding sel berbatas tegas; (2): Hepatosit degenerasi \\
parenkimatosa, terjadi pembengkakan sel disertai \\
sitoplasma keruh dan bergranula; (3): Hepatosit \\
degenerasi hidropik, tampak sel sembab, terdapat \\
akumulasi cairan dan terdapat banyak vakuola; (4): \\
Nekrosis, kerusakan permanen sel atau kematian sel
\end{tabular}

pemeriksaan konsentrasi SGPT, SGOT, HSI dan skoring histopatologi hati mencit diuji homogenitas dan normalitas. Data yang didapatkan terbukti homogen dan terdistribusi normal kemudian dilanjutkan analisis data menggunakan uji statistik ANOVA (Analysis of Varians). Hasil uji menunjukkan adanya perbedaan yang signifikan maka dilanjutkan analisis data dengan uji lanjut Duncan menggunakan taraf kepercayaan $95 \%$.

\section{HASIL DAN PEMBAHASAN}

Serum Glutamat Piruvat Transaminase (SGPT) merupakan enzim yang dapat ditemukan di sel - sel hati, otot, ginjal , jantung dan sebagian besar ditemukan di sitoplasma sel hati (Abidin and Mardiyantoro, 2020). Porsi lebih sedikit ditemukan pada pankreas, paru, limpa dan eritrosit (Sacher and Mcpherson, 2004). Pemeriksaan konsentrasi SGPT dapat memberikan informasi yang lebih spesifik dan sensitif terhadap kerusakan hepatoseluler akut dibandingkan dengan konsentrasi SGOT. Kadar normal SGPT mencit yaitu 2,1 - 23,8 U/L (Abdulkadir and Tungadi, 2017). Hasil pemeriksaan kadar SGPT dan SGOT menggunakan spektrofotometer BTS 350 disajikan pada Tabel 2.

Hasil analisis statistik kadar SGPT mencit dengan One Way Anova memperlihatkan nilai sig. sebesar 0,00 $(\mathrm{P}<0,05)$ yang berarti pemberian ekstrak etanol daun rambutan dengan variasi dosis
Tabel 2. Hasil Pemeriksaan Kadar SGPT dan SGOT $(n=5)$

\begin{tabular}{cll} 
& \multicolumn{3}{c}{ dan SGOT $(\mathbf{n}=\mathbf{5})$} \\
\hline Kelompok & SGPT U/L & SGOT U/L \\
\hline K- & $59,40^{\mathrm{d}} \pm 3,04$ & $109,40^{\mathrm{e}} \pm 8,44$ \\
K+ & $12,80^{\mathrm{a}} \pm 2,16$ & $29,60^{\mathrm{a}} \pm 4,66$ \\
P1 & $32,40^{\mathrm{b}} \pm 3,43$ & $82,00^{\mathrm{b}} \pm 4,47$ \\
P2 & $22,80^{\mathrm{c}} \pm 3,42$ & $55,40^{\mathrm{c}} \pm 4,61$ \\
P3 & $19,60^{\mathrm{c}} \pm 1,81$ & $38,60^{\mathrm{d}} \pm 4,03$ \\
\hline
\end{tabular}

Keterangan: Superskrip dengan huruf a berarti berbeda bermakna dengan kelompok kontrol negatif dan huruf $b$ berarti berbeda bermakna dengan kelompok kontrol positif. K- (Kontrol Negatif), K+ (Kontrol Positif), P1 (Ekstrak dosis 100mg/kgBB), P2 (Ekstrak dosis 200mg/kgBB), P1 (Ekstrak dosis $400 \mathrm{mg} / \mathrm{kgBB}$ ), SD (Standard Deviation).

mampu memberikan perbedaan yang bermakna terhadap konsentrasi SGPT mencit.

Pemberian ekstrak etanol daun rambutan memperlihatkan adanya efek hepatoprotektor namun tidak lebih besar dibanding efek yang diberikan kontrol positif (curcuma). Hal ini dibuktikan dari konsentrasi SGPT kelompok perlakuan (P1, P2 dan P3) dengan kelompok kontrol negatif berbeda signifikan sehingga, pemberian ekstrak etanol daun rambutan terbukti secara statistik mampu mempertahankan kadar SGPT (memiliki efek hepatoprotektor) terhadap mencit yang diiberikan parasetamol dosis toksik.

Serum Glutamate Oksaloasetat Transaminase (SGOT) merupakan enzim yang ditemukan di sel - sel jantung, hati, paru - paru, limpa, ginjal, pankreas, otak dan otot rangka dengan tingkat tertinggi ditemukan di sel - sel jantung (Abidin and Mardiyantoro, 2020). Sehingga pemeriksaan konsentrasi SGOT memberikan hasil yang tidak spesifik terhadap kerusakan sel hati dibandingkan dengan SGPT. Konsentrasi SGOT akan menjadi lebih tinggi jika terjadi nekrosis jaringan yang lebih hebat. Konsentrasi normal SGOT pada mencit adalah 23,2 - 48,8 U/L (Abdulkadir and Tungadi, 2017).

Hasil pengujian statistik kadar SGPT mencit menggunakan One Way Anova juga didapatkan nilai sig. sebesar 0,00 yang berarti pemberian ekstrak etanol daun rambutan dengan variasi dosis mampu memberikan perbedaan yang bermakna terhadap 
konsentrasi SGOT mencit. Pemberian ekstrak etanol daun rambutan memperlihatkan efek hepatoprotektor namun tidak lebih besar dari kontrol positif (curcuma). Hal ini dibuktikan dari konsentrasi SGOT kelompok P1 terlihat mengalami penurunan secara signifikan terhadap kelompok kontrol negatif. Hasil uji juga memperlihatkan kelompok P3 mengalami penurunan konsentrasi SGOT tertinggi dibanding kelompok $\mathrm{P} 1$ dan $\mathrm{P} 2$.

Aktivitas hepatoprotektor ekstrak etanol daun rambutan menunjukkan hubungan yang berbanding lurus dengan banyaknya dosis yang diberikan. Semakin tinggi dosis ekstrak yang diberikan maka semakin mampu mempertahankan konsentrasi SGPT dan SGOT dalam rentang normal.

Organ hati kelompok kontrol positif terlihat berwarna merah kecoklatan dengan permukaan yang licin dan rata. Berbeda dengan kelompok kontrol negatif yang menunjukkan warna hati pucat dan berbintik. Sementara itu, hati kelompok perlakuan menunjukkan semakin meningkatnya dosis ekstrak etanol daun rambutan, warna hati menjadi semakin merah kecoklatan mendekati hati normal pada kontrol positif serta permukaan yang licin dan rata. Pengamatan makroskopis hati mencit menunjukkan bahwa pemberian ekstrak etanol daun rambutan memiliki pengaruh pada penampakan makroskopis hati. Hal ini dapat dilihat berdasarkan perbedaan warna dan permukaan organ hati. Warna hati yang normal yaitu merah kecoklatan serta permukaanya rata dan halus, sementara hati yang mengalami kerusakan atau abnormal akan mengalami perubahan warna menjadi lebih pucat dan permukaan seperti jaringan ikat, kista dan berbintik (Robbins and Kumar, 1992).

Hasil uji statistik bobot hati relatif memakai One Way Anova memperlihatkan nilai sebesar $0,01(\mathrm{P}<0,05)$, berarti pemberian ekstrak etanol daun rambutan mampu memberikan perbedaan yang bermakna terhadap bobot hati relatif mencit. Hasil yang didapat menunjukkan semakin besar dosis ekstrak etanol daun rambutan yang digunakan maka bobot hati relatifnya semakin mendekati

Tabel 3. Bobot Hati Relatif Mencit $(n=5)$

\begin{tabular}{cl}
\hline Kelompok & Bobot Hati Relatif $(\%)$ \\
\hline K- & $6,56^{\mathrm{b}} \pm 1,21$ \\
K+ & $4,65^{\mathrm{a}} \pm 0,65$ \\
P1 & $5,46^{\mathrm{a}} \pm 0,63$ \\
P2 & $5,27^{\mathrm{a}} \pm 0,56$ \\
P3 & $4,93^{\mathrm{a}} \pm 0,68$ \\
\hline
\end{tabular}

Keterangan: Superskrip dengan huruf a berarti berbeda bermakna dengan kelompok kontrol negatif dan huruf $b$ berarti berbeda bermakna dengan kelompok kontrol positif. K- (Kontrol Negatif), K+ (Kontrol Positif), P1 (Ekstrak dosis 100mg/kgBB), P2 (Ekstrak dosis 200mg/kgBB), P1 (Ekstrak dosis $400 \mathrm{mg} / \mathrm{kgBB}$ ), SD (Standard Deviation)

kontrol positif.

Bobot hati relatif kelompok $\mathrm{K}$ memberikan persen bobot yang paling besar dan melebihi nilai normal (Tabel 3). Hal ini dikarenakan induksi parasetamol dosis toksik menyebabkan hati mengalami pembengkakan dan juga didukung dengan hasil makroskopis kelompok $\mathrm{K}$ - yang menunjukkan adanya pembengkakan. Banyaknya cairan yang tertahan dalam membran sel mengakibatkan sel membengkak sehingga pengaturan cairan ke dalam sel akan terganggu. Gangguan tersebut menyebabkan terjadinya influks air yang masuk ke dalam sel. Organel sel seperti mitokondria dan retikulum endoplasma berubah menjadi kantong-kantong berisi air. Mekanismenya ialah diketahui terdapat berbagai jenis elektrolit dalam cairan tubuh baik yang di luar maupun dalam sel seperti ion $\mathrm{K}^{+}$dan $\mathrm{Na}^{+}$. Keseimbangan kedua ion tersebut mesti terkontrol agar kestabilan lingkungan internal sel tetap terjaga. Ion $\mathrm{Na}^{+}$ mesti dipompa keluar sel. Akan tetapi, bila sel mengalami kerusakan maka kemampuannya untuk memompa ion $\mathrm{Na}^{+}$keluar akan terganggu sehingga terjadi influks air ke dalam sel yang menyebabkan sel membengkak (Dewi and Saraswati, 2009).

Hasil pengamatan mikroskopis hati mencit yang diberikan parasetamol dosis toksis menunjukkan adanya perubahan histologi (Tabel 4). Perubahan yang diamati 
Tabel 4. Skor Kerusakan Organ Hati $(n=5)$

\begin{tabular}{cl}
\hline Kelompok & Skor rata-rata \\
\hline K- & $561,26^{\mathrm{b}} \pm 46,67$ \\
$\mathrm{~K}+$ & $294,2^{\mathrm{a}} \pm 22,45$ \\
P1 & $437,867^{\mathrm{a}} \pm 15,68$ \\
P2 & $368,00^{\mathrm{a}} \pm 40,39$ \\
P3 & $301,93^{\mathrm{a}} \pm 22,78$ \\
\hline
\end{tabular}

Keterangan: Superskrip dengan huruf a berarti berbeda bermakna dengan kelompok kontrol negatif dan huruf $b$ berarti berbeda bermakna dengan kelompok kontrol positif . K- (Kontrol Negatif), K+ (Kontrol Positif), P1 (Ekstrak dosis 100mg/kgBB), P2 (Ekstrak dosis 200mg/kgBB), P1 (Ekstrak dosis $400 \mathrm{mg} / \mathrm{kgBB}$ ), SD (Standard Deviation).

meliputi degenerasi parenkimatosa, degenerasi hidropik dan nekrosis. Pada kelompok kontrol negatif yang hanya diberikan suspensi $\mathrm{Na}$ CMC 0,5\% tanpa adanya perlindungan terhadap hati mencit menunjukkan hasil dengan nilai skoring tertinggi dibandingkan kelompok lainnya, dapat dilihat dengan banyaknya jumlah sel nekrosis dan degenerasi parenkim (Tabel 4). Hal ini menunjukkan bahwa pemberian parasetamol dosis toksik mampu menyebabkan perubahan histopatologi hati mencit. Perubahan yang terjadi merupakan akibat dari efek radikal bebas parasetamol yang berikatan dengan hepatosit.

Pada kelompok P1 menunjukkan masih terdapat banyak nekrosis dan degenerasi namun tidak sebanyak kelompok kontrol negatif sama halnya dengan kelompok P2. Hal ini membuktikan bahwa adanya pemberian ekstrak etanol daun rambutan mampu menurunkan cedera yang disebabkan zat toksik seperti parasetamol dosis toksik jika dibandingkan dengan kondisi hati mencit saat hanya diberi parasetamol.

Sementara itu, kelompok P3 yang diberikan ekstrak dosis $400 \mathrm{mg} / \mathrm{kgBB}$ menunjukkan adanya penurunan yang signifikan karena jumlah sel yang mengalami nekrosis dan degenerasi semakin sedikit dengan skoring kerusakan hati sebesar 301,93 sehingga dapat dikatakan mampu mengurangi persentase kerusakan hepatosit mencit. Hal ini membuktikan bahwa ekstrak etanol daun rambutan dosis $400 \mathrm{mg} / \mathrm{kgBB}$ mampu melindungi hati mencit.

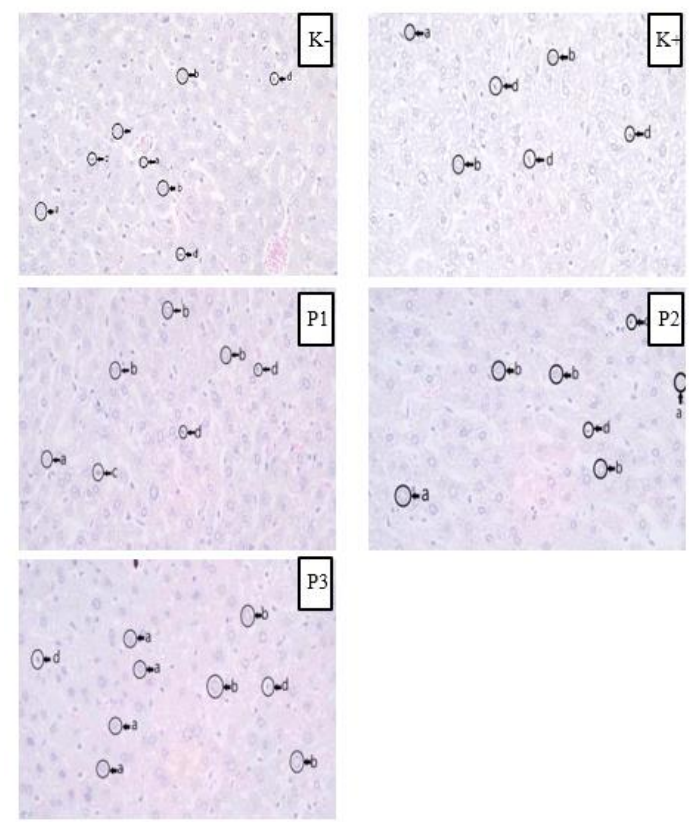

Gambar 1. Histologi hati mencit, a (Normal), b (Degenerasi Parenkim), c (Degenerasi Hidropik), d (Nekrosis).

Kondisi hati yang normal seringkali terdapat nekrosis dan degenerasi sel tetapi jumlahnya tidak banyak (Gambar 1). Jika terdapat senyawa toksik yang dapat merusak hati, maka jumlah sel yang mengalami nekrosis dan degenerasi semakin banyak (Indahsari, 2017). Degenerasi adalah tanda awal terjadinya kerusakan sel yang disebabkan senyawa toksik. Degenerasi diartikan sebagai kelainan sel yang terjadi karena adanya cidera ringan yang mengenai struktur sel sehingga menggangu proses metabolisme. Kerusakan ini bersifat reversible (masih dapat diperbaiki) jika penyebabnya segera dihilangkan. Jika tidak, sel akan menjadi nekrosis sehingga sifatnya irreversibel (Nazarudin et al., 2017).

Degenerasi parenkimatosa diartikan sebagai degenerasi paling ringan yang ditandai dengan adanya sel yang membengkak akibat ketidakmampuan sel dalam mengeliminasi air sehingga tertimbun di dalam sel. Hal ini disebabkan karena 
adanya gangguan pada mitokondria dan retikulum endoplasma akibat oksidasi. Sementara itu, degenerasi hidropik merupakan derajat kerusakan yang lebih berat dibanding degenerasi parenkim yang ditandai dengan adanya vakuolisasi berisi air di dalam sitoplasma (Alamsyah et al., 2021). Perubahan ini diakibatkan adanya gangguan metabolisme seperti keracunan zat kimia. Degenerasi hidropik bersifat reversible meskipun tidak menutup kemungkinan menjadi irreversible bila penyebabnya tidak dihilangkan. Sel yang rusak mampu mengalami robekan pada membran plasma dan terjadi perubahan inti sehingga sel mengalami nekrosis (Utomo et al., 2012).

Nekrosis adalah kematian sel yang terjadi secara tidak terkontrol dan disebabkan karena adanya kerusakan sel akut (Irmawarti and Primiani, 2017). Warna inti sel yang menghitam dan mengalami fragmentasi dapat dicirikan sebagai sel yang nekrosis. Sel juga akan terlihat mengecil dan berkerut sehingga bentuknya menjadi tak teratur (Utomo et al., 2012). Proses nekrosis dimulai dengan inti sel yang mengalami perubahan menjadi lebih hitam (piknosis), kemudian pecah (karioheksis) dan hilang (kariolisis). Terjadinya piknosis disebabkan karena bagian dalam sel mengalami kerusakan seperti kerusakan pada apparatus golgi dan mitokondria. Kerusakan ini menyebabkan ketidakmampuan sel dalam mengeliminasi air dan trigliserida sehingga air tertimbun pada sitoplasma sel (Robbins and Kumar, 1992)

Hasil penelitian menunjukkan bahwa tiap kelompok perlakuan mengalami perubahan histologi hati yang dilihat berdasarkan hasil skoring (Tabel 4). Hasil skoring menunjukkan bahwa pada kelompok perlakuan yang diberikan ekstrak etanol daun rambutan mampu memberikan efek hepatoprotektor. Hal ini dapat dibuktikan dengan adanya penurunan hasil skoring dari tiap perlakuan. Semakin tinggi dosis ekstrak etanol daun rambutan yang diberikan maka hasil skoring akan semakin menurun mendekati kontrol positif yang berarti kerusakan hati mencit semakin kecil.

Efek hepatoprotektor ekstrak etanol daun rambutan kemungkinan disebabkan karena adanya aktivitas antioksidan kuat dalam ekstrak etanol daun rambutan yang memiliki nilai $\mathrm{IC}_{50}$ sebesar $25,47 \mu \mathrm{g} / \mathrm{mL}$ (Pangaribuan et al., 2016). Aktivitas antioksidan tersebut terjadi karena adanya senyawa flavonoid, tannin dan saponin. Flavonoid dan tannin memiliki mekanisme hepatoprotektor yang sama karena keduanya merupakan senyawa fenolik (mempunyai gugus $\mathrm{OH}$ ) yaitu berfungsi sebagai penangkap radikal bebas. Hal ini membuat keduanya mampu mendonorkan atom hidrogen dengan cara mereduksi radikal bebas ke bentuk yang lebih stabil. Keduanya mampu mengikat radikal bebas ataupun metabolit toksik obat secara langsung sehingga mampu menghambat terjadinya kerusakan hati (Gu"lcsin et al., 2010). Sementara itu, aktivitas hepatoprotektor saponin disebabkan karena kemampuannya dalam membentuk spesies reaktif seperti superoksida dan hidroperoksida sebagai antioksidan sehingga mampu menghambat terbentuknya lipid peroksida (Gusungi et al., 2020).

\section{KESIMPULAN}

Pemberian ekstrak etanol daun rambutan (Nephelium lappaceum L.) pada mencit mampu melindungi hati dari paparan parasetamol dosis toksik yang ditandai dengan penurunan kadar SGPT, SGOT, bobot relatif hati serta skoring histopatologi hati mencit. Ekstrak etanol daun rambutan dosis $400 \mathrm{mg} / \mathrm{KgBB}$ merupakan dosis optimal yang memberikan efek hepatoprotektor karena mampu mempertahankan kadar SGPT sebesar 19,60 U/L, SGOT 38,60 U/L dan bobot hati relatif sebesar 4,93 serta skoring histopatologi sebesar 301,93. 


\section{Daftar Pustaka}

Abdulkadir W.S. and Tungadi R., 2017, The hepatoprotective effect of sea cucumber (Holothuria scabra) extract originating from gorontalo district using SGOT and SGPT parameters on mice induced by hepatotoxic dose Of paracetamol, International Journal of ChemTech Research, 10 (7), 105-111.

Abidin Z.Z. and Mardiyantoro F., 2020, Diagnosis dan tata laksana perdarahan rongga mulut, Universitas Brawijaya Press, Malang.

Alamsyah, Chaasani S., Widodo J.W., Nasihul T., Chodidjah and Sumarawati T., 2021, Pengaruh ekstrak propolis (metode CMCE) terhadap kadar malondialdehid (MDA) dan degenerasi tubulus renalis, Jurnal Litbang Edusaintech, 2 (1), 1-7.

BPOM RI, 2014, Peraturan Kepala Badan Pengawas Obat Dan Makanan Republik Indonesia Nomor 7 Tahun 2014,

Dart R.C., 2004, Medical toxicology, 3rd ed., Lippincott Williams and Wilkins, Philadelphia.

Dewi U.K. and Saraswati T.R., 2009, Efek rebusan daun tapak dara pada dosis dan frekuensi yang berbeda terhadap kerusakan dan akumulasi glikogen pada hepar mencit (Mus musculus), BIOMA, 11 (1), 1-5.

Gu“lc,in I., Huyut Z., Elmastas M. and Aboul-Enein H.Y., 2010, Radical scavenging and antioxidant activity of tannic acid, Arabian Journal of Chemistry, 3 (1)

Gunawan G.S., 2016, Farmakologi dan Terapi Edisi 6, Universitas Indonesia Press, Jakarta.

Gusungi D.E., Maarisit W. and Potalangi N.O., 2020, Studi aktivitas antioksidan dan antikanker payudara (MCF-7) ekstrak etanol daun benalu angsat Dendrophthoe pentandra, Jurnal Biofarmasetikal Tropis, 3 (1), 166-174.

Hidayat S. and Napitupulu R.M., 2015, Kitab tumbuhan obat, Agriflo, Jakarta.

Indahsari N.K., 2017, Gambaran histopatologi hepar tikus putih (Rattus Novergicus) yang diinduksi dengan parasetamol dosis toksik pasca pemberian ekstrak etanol daun kelor (Moringa Oleifera), Jurnal Kimia Riset, 2 (2), 123.

Irmawarti F. and Primiani C.N., 2017, Perbandingan uji toksisitas fitoestrogen pada ginjal tikus (sprangue dawley) yang diinduksi daidzein dan air perasan umbi bengkuang (Pachyrhizus erosus), Bioeksperimen, 3 (2), 52-60.

Jurnalis Y.D., Sayoeti Y. and Elfitrimelly, 2014, Peran antioksidan pada non alcoholic fatty liver disease (NAFLD), Jurnal Kesehatan Andalas, 3 (1), 15-20.

Meisyayati S., Safitri and Hasanah M., 2017, Efek hepatoprotektor beberapa fraksi dari ekstrak daun sukun (Artocarpus altilis) terhadap mencit putih jantan galur swiss webster yang diinduksi parasetamol, Scientia, 7 (2)

Nazarudin Z., Muhimmah I. and Fidianingsih I., 2017, Segmentasi citra untuk menentukan skor kerusakan hati secara histologi, Seminar Nasional Informatika Medis (SNIMed) VIII, $15,15-21$.

Neal M.J., 2006, At a Glance Farmakologi Medis, Erlangga, Jakarta.

Pangaribuan F.X.R., Sitorus S. and Saleh C., 2016, Uji Fitokimia dan Aktivitas Antioksidan Ekstrak Daun rambutan (Nephelium lappaceum) Dengan Metode DPPH (1, 1-diphenyl- 
2-picryhidrazyl), Jurnal Atomik, 01 (2), 81-85.

Robbins S.L. and Kumar V., 1992, Buku ajar patologi 1, EGC, Jakarta.

Sancher R.A. and Mcpherson R.A., 2004, Tinjauan klinis hasil pemeriksaan laboratorium, EGC, Jakarta.

Sudjono T.A., Widiatmoko Y.W. and Karuniawati H., 2012, Efek infusa bunga rosella (Hibiscus sabdariffa) pada serum glutamte piruvat transaminase tikus yang diinduksi parasetamol dosis toksik, Pharmacon: Jurnal Farmasi Indonesia, 13 (2), 65-69.

Utomo Y., Hidayat A., Dafip M. and Sasi F.A., 2012, Studi histologi hati mencit (Mus musculus L.) yang diinduksi pemanis buatan, Jurnal MIPA, 35 (2), 122-129. 